\title{
Relationship of Food Security and Land Ecology in West Lombok Regency
}

\author{
Mira Juwita* \\ Study Program of Dryland Agriculture \\ Postgraduate Study \\ University of Mataram \\ Indonesia \\ mira.juwita80@gmail.com
}

\author{
Taslim Sjah \\ Study Program of Dryland Agriculture \\ Postgraduate Study \\ University of Mataram \\ Indonesia \\ taslimsjah@unram.ac.id
}

\author{
Bambang Dipokusumo \\ Study Program of Dryland Agriculture \\ Postgraduate Study \\ University of Mataram \\ Indonesia \\ bambangdipokusumo@unram.ac.id
}

\begin{abstract}
The goal of the study is to examine the relationship of food security and land ecology in West Lombok Regency. This study uses secondary data from Central Statistics Agency of West Lombok Regency and collects time series data of year 2016 to 2019. Related data from other sources are also accessed to complement the main analysis. The results showed that land ecology of West Lombok has relationship with food security in region, with strong indications that wetland ecology has higher food security level than dryland ecology. This study recommends the transformation of dryland into wetland, for example, by building irrigation infrastructure whenever and wherever possible. Wetland is obviously more productive in provision of food than its counterpart.
\end{abstract}

Keywords-agricultural development, food security, land ecology, dryland, wetland

\section{INTRODUCTION}

Food security is not only a matter of production, but also the aspects of social, economic and health. The ability of a region to produce food does not guarantee food security. In other words, sufficient food availability does not necessarily mean that an area is in food security. Food insecurity is not only caused by low food production but also by how people can access and use the food itself.

Population growth in dry land areas has decreased the quality and potential of dry land production. This is partly due to population pressure which results in a decrease in the ability of natural resources to revitalize their function to support the farming system. Research conducted by FAO [1] in Kasryno and Soeparno [2], shows that the causes of damage to dry land resources are very complex, mainly due to policy failures and market failures rather than farmers' failure to manage dry land. In general, the government does not pay enough attention to sustainable dryland management.

NTB Province has a comparative advantage in developing dry land agriculture. The fact shows that the province of NTB has a dry land area of $83.4 \%$, which is much larger than the area of rice fields $(12.3 \%)$. Of the dry land area of NTB which reaches 1.84 million ha, there are around 749,000 ha can potentially be developed into productive dry land agriculture. At this time, the large potential of dry land owned by NTB is only around 30\% which is utilized with simple technology so that it has not been able to make a significant contribution to improving the welfare of farmers [3].
Judging from the vast area of dry land, most of the populations of NTB live in dry land areas. West Lombok Regency with a dry land area of 60,274 ha or $71.96 \%$ has $64.17 \%$ of the population lives in dry land areas spread over 6 districts of 10 districts, i.e.Sekotong, Lembar, Narmada, Lingsar, Gunungsari and Batulayar. Meanwhile, the other 4 districts, i.e.Gerung, Labuapi, Kediri and Kuripan, are located in rice fields (wetland).

Food security has not been achieved when only food availability is fulfilled. Food security will be achieved when access to food is adequate and food absorption can take place properly. The availability of adequate and even excess food is not accompanied by adequate access to food resulting in inadequate absorption of food so that many regions have not been able to achieve food security even though they have reached a food surplus.

Systematically, the problem of food security can be seen from three aspects, i.e. food availability, access and consumption. Based on data from DKP NTB, the Province of NTB has experienced a surplus for the last 15 years, but there are still villages that are classified as food insecure. These two sides need to find common ground so that regional food security can be realized.

The research objective was to assess household food security from the ecological aspects of rice fields and dry land in West Lombok Regency. This research is expected to be useful in determining regional policies, especially those related to food security policies.

\section{METHODS}

The research method used is descriptive analytical method, which by Surakhmad [4] is defined as a study that focuses on solving problems that exist in the present, by collecting, analyzing and concluding in the context of theories and results of previous research. Descriptive method is a research activity with the aim of explaining, making a description of a symptom or object under study using the data obtained. According to the narrow sense, descriptive research can also be interpreted as research which only shows pictures, descriptions or details about the symptoms or objects under study. But in a broad sense, descriptive research further tells the relationship or linkages between symptoms (variables) and how far there is agreement or the results conveyed.

This research is a secondary data analysis research and statistical data analysis by collecting existing data in the 
service/agency and then analyzed [5]. The unit of analysis in this research is the district to see the relationship of food security in the wetland and dry land communities in West Lombok Regency. Data collection is carried out by collecting secondary data on related agencies. This study uses data for 14 years, from 2006 to 2020 .

The analytical tools used to answer the research objectives are analysis of food availability, food access and food utilization.

According to DKP NTB [5], to analyze the food availability ratio, secondary data is used in the form of production of rice, maize, cassava and sweet potato in West Lombok Regency with the following formula (DKP, 2019) :

$$
I=\operatorname{Cn} /\left[\frac{P d \text { netto }}{t p * 365}\right]
$$

Description

I : Food Availability Ratio;

Pdnetto :Total Net Production of Serealia (gr)

Tp : Total Population (person)

Cn : Konsumsinormatif (300gr/kap/hari)

The second aspect of food security is access to food and livelihood; this is seen from the Poor Population, Household Expenditure on Food and Access to Electricity. descriptively, an area is said to be food insecure if the percentage of poor people reaches $25 \%$ or more, the percentage of households with expenditure on food is more than $65 \%$ of the total expenditure reaches $40 \%$ or more and the percentage of households without access to electricity is more than $40 \%$ [6].

An area is said to be food insecure from the aspect of food utilization if the percentage of illiterate women is more than $30 \%$, the average length of school for women is less than 6 years, the percentage of households without access to clean water is more than $60 \%$ and the ratio of population per health worker to the level of population density of more than $20 \%[6]$.

All food security variables were analyzed for a composite analysis to determine the food security index using the formula [6]:

$$
\boldsymbol{Y} j=\sum_{i=1}^{\infty} \boldsymbol{a} i \boldsymbol{X} i j
$$

Description:

$\mathrm{Yj} \quad$ : jthdistric composite scor

ai :The weight of eachith variable

$\mathrm{Xij}$ :The standardization value of each of the i-th indicators in the $\mathrm{j}$-district

i :variable 1 st, 2 nd, ..., 9th

j :Disctrict 1st, 2nd, ...dst

Food security analysis can be seen from food security priorities by looking at the range of each variable. Priorities 1 and 2 are categorized as food insecure areas, priorities 3 and 4 are categorized as food insecurity and priorities 5 and 6 are categorized as food security. The bigger the priority, the more food resistant.

To examine the relationship between food security and land ecology, a simple regression equation is used as follows:

Description,

$$
Y=\alpha+\beta X
$$

Y: Food Security

$\mathrm{X}$ :Paddy and Dry Land Ecology (paddy land =1; dry land $=0$ )

\section{RESULT AND DISCUSSION}

\section{General Condition of Research Area}

West Lombok Regency is one of ten regencies or municipalities in the NTB Province. Geographically, West Lombok Regency is at 115049,12'04 "to 116020'15.62" East Longitude and 8024'33.82 "to 8055'19" South Latitude, with an area of 1,053.92 km2 (105,392 ha) [7]

The area of land or land in West Lombok Regency is $8,618.2 \mathrm{~km} 2(86,182 \mathrm{ha})$, consisting of 16,901 ha of paddy land and an area of dry land50,658 ha and 86,182 ha of nonagricultural land. Thus, it appears that the land in West Lombok Regency has the potential for dry land with a percentage of $74.98 \%$ and the potential for wet or wetland with a percentage of $25.02 \%$.

Land use in West Lombok Regency is dominated by dry land of 50,658 ha and rice fields of 16,901 ha. The subdistrict with the widest dry land area is the Sekotong subdistrict with an area of 22,590 ha, followed by Narmada District with an area of 7,326 ha and Lingsar District with an area of 6,006 ha. Meanwhile, the sub-district with the smallest dry land area is Kediri District with an area of 322

\begin{tabular}{|c|c|c|c|c|c|c|}
\hline No & District & Paddy Land & $\begin{array}{l}\text { Non-Paddy Land } \\
\text { (Dry Land) }\end{array}$ & Agriculture land area & \% Non-Paddy Land & Land Ecology \\
\hline 1 & Sekotong & 3.040 & 22.590 & 25.630 & 88,14 & Dry Land \\
\hline 2 & Lembar & 2.090 & 4.053 & 6.143 & 65,98 & Dry Land \\
\hline 4 & LabuApi & 1.456 & 436 & 1.892 & 23,04 & Paddy Land \\
\hline 5 & Kediri & 1.450 & 322 & 1.772 & 18,17 & Paddy Land \\
\hline 6 & Kuripan & 1.072 & 850 & 1.922 & 44,22 & Paddy Land \\
\hline 7 & Narmada & 2.242 & 7.326 & 9.568 & 76,57 & Dry Land \\
\hline 8 & Lingsar & 1.849 & 6.006 & 7.855 & 76,46 & Dry Land \\
\hline 9 & Gunung Sari & 905 & 4.017 & 4.922 & 81,61 & Dry Land \\
\hline 10 & Batu Layar & 240 & 2.656 & 2.896 & 91,71 & Dry Land \\
\hline \multicolumn{2}{|c|}{ Lombok Barat } & 16.901 & 50.658 & 67.559 & 74,98 & Dry Land \\
\hline
\end{tabular}
ha. For more details, see Table I.

TABLE I. AGRICULTURALLAND ÁREA BASEDONLANDECOLOGY IN WEST LOMBOK REGENCY, 2014

Source: BPS West Lombok (2016) 
The area of agricultural land in Table I shows that it appears that there are 4 districts that are included in the ecology of paddy fields because the percentage of non-rice fields is below 50\%, namely Gerung District, Labuapi District, Kediri District and Kuripan District. While the subdistricts that are included in dry land ecology because the percentage of non-rice fields is above $50 \%$, there are 6 subdistricts, namely Sekotong District, Lembar District, Narmada District, Lingsar District, Gunungsari District and Batu LayarDistrict.

\section{Food Availability}

The indicator of food availability used for food security analysis is the ratio of food availability by looking at the ratio of per capita normative consumption to net cereal production. The ratio shows whether an area has a surplus or deficit in cereal production. Cereal production at the subdistrict level is calculated by taking the average production of rice, maize, cassava and sweet potato for 14 years. The net availability of cereals per capita is calculated by dividing the total cereal production in a particular sub-district by the population. Then the ratio of per capita normative consumption to net cereal production is calculated. Based on Indonesia's consumption profile, cereal consumption per capita per day is 300 grams.

TABLE II. NET PRODUCTION, NET PRODUCTION PER CAPITA PER YEAR AND FOOD AVAILABILITY RATIO BY DISTRICT IN WEST LOMBOK REGENCY, 2006-2019

\begin{tabular}{|c|c|c|c|c|c|c|c|c|}
\hline \multirow{2}{*}{ No. } & \multirow{2}{*}{ District } & \multicolumn{5}{|c|}{ ProduksiBersih (Ton) } & \multirow{2}{*}{$\begin{array}{c}\text { Net prod/ capita/ } \\
\text { year }\end{array}$} & \multirow[b]{2}{*}{ Avalaibility Ratio } \\
\hline & & Rice & Corn & Cassava & Sweet Potato & Total & & \\
\hline 1 & Sekotong & 9,882 & 10,376 & 1,217 & 565 & 22,040 & 999.36 & 0.30 \\
\hline 2 & Lembar & 7,720 & 6,887 & 470 & 197 & 15,274 & 875.55 & 0.34 \\
\hline 4 & LabuApi & 10,037 & 1,077 & 11 & 12 & 11,137 & 466.76 & 0.64 \\
\hline 5 & Kediri & 8,360 & 3,165 & 10 & 22 & 11,557 & 543.53 & 0.55 \\
\hline 6 & Kuripan & 6,226 & 2,237 & 65 & 58 & 8,586 & 642.98 & 0.47 \\
\hline 7 & Narmada & 17,091 & 10 & 1,120 & 10 & 18,231 & 528.07 & 0.57 \\
\hline 8 & Lingsar & 14,482 & 55 & 192 & 86 & 14,815 & 586.27 & 0.51 \\
\hline 9 & Gunungsari & 5,613 & 652 & 1,191 & 239 & 7,695 & 249.41 & 1.20 \\
\hline 10 & Batu Layar & 1,419 & 70 & 543 & 40 & 2,073 & 116.36 & 2.58 \\
\hline \multicolumn{2}{|c|}{ Lombok Barat } & 94,898 & 32,167 & 5,080 & 1,406 & 133,551 & 566.76 & 0.53 \\
\hline
\end{tabular}

Based on Table II, it can be seen that almost all districts have a surplus because the value of the availability ratio is less than 1 , which means that the consumption needs of the people in a district are met from the net production of rice and cereals in the district. However, there are 2 sub-districts that experience deficits with a food availability ratio of more than 1, namely Gunungsari District and Batu Layar District. This means that the people's consumption needs in the two sub-districts cannot be met from the net production of rice and cereals in the two sub-districts.

The causes of the deficit in availability vary between subdistricts, but generally include: i) conversion of agricultural land to non-agricultural ii) degradation of agricultural land; iii) low productivity; and v) lack of available agricultural land relative to population density.

For all sub-districts, including those with surplus cereal production, climate change is a major concern in relation to high rates of deforestation, drought and / or floods which pose a serious threat to the sustainability of current production levels. Risks from climate change phenomena such as erratic weather patterns, increased intensity of crop pests and natural disasters have the potential to threaten what has been achieved so far and hinder progress in food and nutrition security in West Lombok Regency.

Increasing production or food availability does not always guarantee the fulfillment of food consumption by the community or household. As revealed by Suryana [8], there is a wide enough gap between the average food availability which is more than sufficient and the average food that is actually consumed by the community which is still below the recommendation. The availability of adequate food at the macro level does not necessarily improve the quality of consumption and nutritional status of the community.

\section{West Lombok Regency Food Security}

Many factors can influence the vulnerability of a household to food insecurity. These factors are grouped according to their relationship with three dimensions of food security, namely food availability, food access and utilization of nutrients in food.

In this study, access to food availability was seen from the ratio of food availability to normative consumption of cereals. Meanwhile, access to food by observing 3 variables, namely poverty, household expenditure and access to electricity. For the aspect of food utilization, it can be seen from household access to clean water, women's education and the ratio of population to health workers per density.

Districts that are included in Priority 1 are sub-districts that tend to have a higher level of vulnerability than subdistricts with priority above it. Thus, priority 6 is the subdistricts that tend to be more food resilient. Sub-districts in priority 1,2 and 3 tend to be highly vulnerable to food and nutrition insecurity, while sub-district in priority 4,5 and 6 are in the category of more food resilience.

It is important to remember that not all households in high priority sub-district (priority 1 - 3) are classified as food insecure, nor are all households in low priority sub-district (priority 4-6) classified as food resistant. The objective of this priority setting is to identify which sub-district are more vulnerable to food and nutrition insecurity based on the availability of secondary data. 
Based on the food security composite analysis, 10 subdistricts are grouped into six priority groups as follows: 1 sub-district, namely Batu Layar District, is in priority 3 with a food security index of 44.01 percent, 1 sub-district, Sekotong District, is in priority 3 with a composite index value of 44.01 percent. 51.68 percent, which means that the two sub-districts are included in the food insecurity area. Meanwhile, 8 other sub-districts are included in the foodresistant category with 3 sub-districts included in priority 4, namely Gerung, Narmada and Gunungsari Districts, 2 Subdistricts included in priority 5 and 3 sub-districts included in priority 6. For more details, see Table III.

TABLE III. FOOD SECURITY INDEX IN WEST LOMBOK REGENCY

\begin{tabular}{|c|c|c|c|c|c|c|c|c|c|c|}
\hline \multirow[b]{2}{*}{ Regency } & \multirow{2}{*}{$\begin{array}{c}\text { Food } \\
\text { Availability } \\
\\
\begin{array}{c}\text { Avalability } \\
\text { Ratio }\end{array}\end{array}$} & \multicolumn{3}{|c|}{ Access to Food } & \multicolumn{4}{|c|}{ Utilization ofPangan } & \multirow[b]{2}{*}{ Indeks FS } & \multirow[b]{2}{*}{$\begin{array}{c}\text { Composite } \\
\text { priority }\end{array}$} \\
\hline & & $\begin{array}{c}\% \\
\text { Proverty }\end{array}$ & $\begin{array}{c}\text { \%Food } \\
\text { Expenditure }\end{array}$ & $\begin{array}{c}\text { \% Households } \\
\text { without } \\
\text { electricity }\end{array}$ & $\begin{array}{c}\% \\
\text { Households } \\
\text { without } \\
\text { clean water }\end{array}$ & $\begin{array}{c}\% \\
\text { Illetarate } \\
\text { woman }\end{array}$ & $\begin{array}{c}\text { Length } \\
\text { of } \\
\text { schoo } \\
1 \text { for } \\
\text { girl }\end{array}$ & $\begin{array}{c}\% \\
\text { Health } \\
\text { worke } \\
\text { rs }\end{array}$ & & \\
\hline Sekotong & 0,30 & 27,80 & 60,98 & 13,71 & 27,54 & 34,50 & 4,24 & 1,45 & 51.68 & 3 \\
\hline Lembar & 0,34 & 22,75 & 64,18 & 9,90 & 26,16 & 29,89 & 3,50 & 0,64 & 73,04 & 5 \\
\hline LabuApi & 0,64 & 18,54 & 56,97 & 6,44 & 22,86 & 26,39 & 5,55 & 0,82 & 85,03 & 6 \\
\hline Kediri & 0,55 & 18,78 & 61,07 & 6,20 & 24,04 & 26,97 & 6,00 & 0,93 & 77,47 & 6 \\
\hline Kuripan & 0,47 & 17,64 & 63,80 & 7,73 & 21,96 & 28,10 & 5,94 & 0,87 & 80,15 & 6 \\
\hline Narmada & 0,57 & 19,13 & 63,64 & 8,34 & 24,92 & 28,42 & 8,99 & 1,30 & 59,95 & 4 \\
\hline Lingsar & 0,51 & 18,87 & 65,80 & 5,60 & 24,66 & 31,15 & 4,68 & 0,76 & 74,84 & 5 \\
\hline Gunung Sari & 1,20 & 18,61 & 67,20 & 7,96 & 23,33 & 30,41 & 5,15 & 0,92 & 63,33 & 4 \\
\hline Batu Layar & 2,58 & 18,20 & 58,37 & 7,67 & 28,23 & 28,29 & 7,09 & 0,89 & 44,01 & 2 \\
\hline
\end{tabular}

Source: Result of Food Security Analysis in West Lombok Regency

The main characteristics of vulnerability to food insecurity in each region are different, so the specific approach to reducing vulnerability will also be different in each district. By determining the main characteristics of vulnerability to food insecurity at the sub-district level, this map can provide better guidance for policy makers to improve the effectiveness and determination of food security programs.

Of all sub-districts, the main characteristics that cause high vulnerability to food insecurity are: i) household expenditure on food and; ii) women's education, as indicated by the low average length of schooling for girls.

According to research by Purwaningsih [9], households that have a low share of food expenditure, meaning that less than 60 percent of the share of income is spent on food indicates that the household is categorized as food resistant. while households with food expenditure of more than 65 percent are used to meet food needs, indicating that the household is food resistant

Based on the results of Hayati's research, et al., [10], women play a role in the aspects of food availability, food production and food consumption, including in preparing and distributing food to all household members. This is related to the existence of differences in gender roles that apply in the people of Lombok Island, where women play a role in the implementation of work in the domestic sphere, while men in the public sphere [11].

Several studies have shown that the level of education is positively correlated with people's ability to absorb and receive information and knowledge about health which in turn will increase awareness of the importance of health and healthy living behavior [12-14]

The condition for the fulfillment of food is reflected in the availability of food that is sufficient in quantity and quality, evenly distributed and affordable. Increasing agricultural production is a solution to solve the problem of food security from the supply side. Increasing food production will be more effective by increasing agricultural productivity, such as improving irrigation / agricultural infrastructure, food diversification, agricultural technology, distribution of agricultural products, intensification, extensification, structuring institutional functions, and financing (markets and partnerships). Food and energy security is also influenced by the structure of the population and consumption patterns of society as well as the phenomenon of urbansation so that regional self sufficiency and zoning systems are needed for the production and supply of commodities. [15]

Relationship of Food Security with Paddy and Dry Land Ecology

To see the relationship between land ecology and food security, a simple regression analysis of the dependent variable (Y), namely Food Security, was carried out with the independent variable (X), namely the Ecology of Rice Fields and Dry Lands.

\section{TABLE IV. INDEX OF FOOD SECURITY AND LAND ECOLOGY} IN WEST LOMBOK REGENCY

\begin{tabular}{|c|c|c|c|c|}
\hline No. & Regency & $\mathbf{Y}$ & $\mathbf{X}$ & Land Ecology \\
\hline 1 & Sekotong & 51.68 & 0 & Dry Land \\
\hline 2 & Lembar & 73.04 & 0 & Dry Land \\
\hline 3 & Gerung & 66.55 & 1 & Paddy Land \\
\hline 4 & LabuApi & 85.03 & 1 & Paddy Land \\
\hline 5 & Kediri & 77.47 & 1 & Paddy Land \\
\hline 6 & Kuripan & 80.15 & 1 & Paddy Land \\
\hline 7 & Narmada & 59.95 & 0 & Dry Land \\
\hline 8 & Lingsar & 74.84 & 0 & Dry Land \\
\hline 9 & Gunung Sari & 63.33 & 0 & Dry Land \\
\hline 10 & Batu Layar & 44.01 & 0 & Dry Land \\
\hline
\end{tabular}

Source: Result of Food Security Analysis in West Lombok Regency

Based on the value of the determinant coefficient of R2 of 0.524 , it means that the independent variable (land 
ecology) to the change in the dependent variable (food security) is 52.4 percent, while the remaining 1-52.4 or 47.6 percent is influenced by variables that are not specified in model

When viewed from the $\mathrm{f}$ count of 5.5558 while the significance value is 0.046 which is smaller than 0.05 , it can be concluded that Ho is rejected and Hi is accepted, meaning that ecology has a significant effect on food security.

Hypothesis testing is also called the $t$ test, if the value of $t$ count> from the $\mathrm{t}$ table then Ho is rejected. Based on the table above, it is known that the t value is 2.358 . While the $t$ table is obtained by the formula for the value of a / $2=0.23$ / $2=0.115$ with degrees of freedom $(\mathrm{df})=\mathrm{n}-2=10-2=8$, when viewed on the $\mathrm{t}$ table, the $\mathrm{t}$ table value is 1.396 . Because the $t$ value of 2.965 is greater than> 1.396 ( $t$ table), it can be concluded that Ho is rejected and $\mathrm{Ha}$ is accepted, which means that there is an effect of Land Ecology $(\mathrm{X})$ on Food Security (Y).

$$
Y=61,142+16,158 X
$$

The value of $\mathrm{a}=61.142$ is a constant number which means that if there is no land ecology, the consistent value of food security $(\mathrm{Y})$ is 61.142. The number $b$ (regression coefficient) of 16.158 means that every $1 \%$ addition of land ecology, the value of food security (Y) will increase by 16.158. Because the regression coefficient value is plus (+), it can be said that land ecology $(\mathrm{X})$ has a positive effect on food security (Y).

Based on the results of the statistical test above, it shows that land ecology has a significant effect on food security. The food security index in areas with wetland ecology is higher than the food security index in dryland ecological areas. So that to increase food security is to improve the ecology of an area from dry land to wetland by building and adding to irrigation infrastructure, increasing productivity and limiting the conversion of productive land functions and increasing the area of rice fields.

However, as we know, agricultural land is the type of land that has been converted the most, especially paddy fields. This occurs due to the low incentives or income received by farmers while managing rice fields compared to use for activities for other sectors [16-17]. The high rate of conversion of paddy fields, degradation of agricultural land due to the continuous use of chemical fertilizers, low productivity and lack of availability of agricultural land compared to population density have implications for decreasing food availability for the population so that it will have an impact on decreasing food production, especially rice which can pose a threat for the food security of the population [18]

Production of major commodities such as rice and maize is highly dependent on harvested area and productivity [19]. Land that remains a major factor in increasing agricultural production, especially corn rice and is supported by adequate irrigation [20]. Therefore, supporting facilities are needed in increasing agricultural productivity in Indonesia, one of the most important is the irrigation area, with adequate irrigation that will increase rice productivity in Indonesia [21].
Acording to Distanbun Lobar [22], strategic policies that need to be taken are (1) policies to protect agricultural land, (2) policies to develop food agribusiness areas, both existing land and potential land, (3) policies to develop regional based food reserves, and (4) ) policy for providing incentives for food buffer areas. In real terms, these main policies should also be supported by steps (1) increasing agricultural infrastructure, (2) strengthening agricultural institutions, (3) developing technology and technology applications, (4) increasing access to agricultural capital, and (5) developing marketing. agricultural product. With the improvement of the system and the implementation of these strategic policies, it is hoped that the continuity of food security can be realized.

\section{CONCLUSIONS}

Based on the research results, it can be concluded that the land ecology has a significant effect on food security. The food security index in areas with wetland ecology is higher than the food security index in dryland ecological areas. To be able to increase food security, the Regional Government of West Lombok Regency needs to improve the ecology of land from dry land to wetland. Strategic policies that need to be taken are policies to protect agricultural land, policies to develop food agribusiness areas, both existing and potential lands, policies to develop regional-based food reserves, and policies to provide incentives for food buffer areas. Meanwhile, strategic steps to increase food security are by increasing agricultural infrastructure, strengthening agricultural institutions, developing technology and technology applications, increasing access to agricultural capital, and developing agricultural product marketing.

\section{REFERENCES}

[1] FAO, An. "An introduction to the basic concepts of food security." FAO, Rome, Italy. 2008

[2] Kasryno, Faisal, and Haryono Soeparno. "Pertanian lahan kering sebagai solusi untuk mewujudkan kemandirian pangan masa depan." Prospek Pertanian Lahan Kering dalam Mendukung Ketahanan Pangan. Editor: Dariah, Ai., dkk. Badan Penelitian dan Pengembangan Pertanian. Kementerian Pertanian. 2012

[3] Suwardji. "Potensi, Kebijakan dan Prospekdalam Pengembangan Pertanian Lahan Kering di Provinsi Nusa Tenggara Barat. Program Akses Reforma Agraria Kantor BPN NTB”. 2015.

[4] Surakhmad, Winarno. Pendidikan nasional, strategi, dan tragedi. Penerbit Buku Kompas, 2009.

[5] Sjah, T. "Metodologi Penelitian Sosial Ekonomi. Mataram University Press. Universitas Mataram. Indonesia". 2011.

[6] DKP NTB. "Peta Ketahanan dan Kerentanan Pangan Provinsi NTB Tahun 2019. Dinas Ketahanan Pangan Provinsi Nusa Tenggara Barat. Mataram.”. 2019.

[7] BKP. "Panduan Penyusunan Peta Ketahanan dan Kerentanan Pangan Kabupaten 2020. Badan Ketahanan Pangan Kementerian Pertanian. Jakarta”. 2020.

[8] BPS Lombok Barat. "Kabupaten Lombok Barat dalam Angka 2019. Badan Pusat Statistik Kabupaten Lombok Barat. Gerung”. 2019.

[9] Suryana, Achmad. "Menuju ketahanan pangan indonesia berkelanjutan 2025: tantangan dan penanganannya." 2014.

[10] Purwaningsih, Y., and Masyuhri Slamet Hartono. "Pola Pengeluaran Rumah Tangga Menurut Tingkat Ketahanan Pangan di Propinsi Jawa Tengah." Jurnal Ekonomi Pembangunan Surakarta 9.1. 2010: 1-27.

[11] Hayati, Hayati, et al. "Peningkatan Kemampuan Perempuan dalam Mewujudkan Diversifikasi Pangan Rumah Tangga di Desa Teratak Kecamatan Batukliang Utara, Kabupaten Lombok Tengah." Jurnal Gema Ngabdi 2.1 (2020): 54-62. 
[12] Hayati., Sahidu, A., Muktasam., and Bachri, J. "Peranan Penyuluh dan Perilaku Perempuan Tani dalam Mendukung Ketahanan Pangan Rumah Tangga di Lahan Sawah dan Lahan Kering di Kabupaten Lombok Tengah. Prosiding Seminar Nasional Teknologi Dan Rekayasa Sosial Ekonomi Berkelanjutan Untuk Kedaulatan Pangan Dan Energi Kawasan Pulau-Pulau Kecil. Mataram”. (2018).

[13] Khan, Rana Ejaz Ali, Toseef Azid, and Mohammad Usama Toseef. "Determinants of food security in rural areas of Pakistan." International Journal of Social Economics (2012).

[14] Khan, Rana Ejaz Ali, Toseef Azid, and Mohammad Usama Toseef. "Determinants of food security in rural areas of Pakistan." International Journal of Social Economics (2012).

[15] Mahmood, Shaheen, et al. "Food Poverty and its Causes in Pakistan [with Comments]." The Pakistan Development Review 30.4 (1991): 821-834.

[16] Nazara, Suahasil, and G. Irwan Suryanto. "Memperkuat ketahanan pangan dan energi nasional dalam era persaingan global." Prosiding Sidang Pleno XIII dan Seminar Nasional Ikatan Sarjana Ekonomi Indonesia, Mataram. 2008.

[17] Daulay, Asnelly Ridha, et al. "Rice land conversion into plantation crop and challenges on sustainable land use system in the East
Tanjung Jabung Regency." Procedia-Social and Behavioral Sciences 227. 2016: 174-180.

[18] Prasada, I. Made Yoga, and Tia Alfina Rosa. "Dampak alih fungsi lahan sawah terhadap ketahanan pangan di Daerah Istimewa Yogyakarta." Jurnal Sosial Ekonomi Pertanian 14.3 2018: 210.

[19] Jamil, Ali, et al. "Pembangunan pertanian berbasis persawahan dalam perspektif ekoregion." 2015.

[20] Van Oort, P. A. J., Saito, K., Tanaka, A., Amovin-Assagba, E., Van Bussel, L. G. J., Van Wart, J., De Groot, H., Van Ittersum, M. K., Cassman, K. G., \&Wopereis, M. C. S. "Assessment of Rice SelfSufficiency in 2025 in Eight African Countries". Global Food Security, 5, 39-49. https://doi.org/10.1016/j.gfs. 2015.

[21] Dube, Sikhalazo, et al. "South African food security and climate change: Agriculture futures." Economics: The Open-Access, OpenAssessment E-Journal 7.2013-35. 2013: 1-54.

[22] Motevali, Ali, et al. "Energy analyses and drying kinetics of chamomile leaves in microwave-convective dryer." Journal of the Saudi Society of Agricultural Sciences 15.2. 2016: 179-187.

[23] Distanbun Lombok Barat, "Laporan Tahunan Dinas Pertanian dan Perkebunan Kabupaten Lombok BaratTahun 2019. Dinas Pertanian dan Perkebunan Kabupaten Lombok Barat. Gerung. 2020. 